itative, yet the reader should remember that some of the statements made are really matters of opinion of the writers concerned and not universally agreed upon. For example, a number of investigators cannot agree with the statement at the top of page 21, and will affirm on the contrary that the industries in the top gravels of the $100-\mathrm{ft}$. terrace below London are indeed quite late and do belong to the same series as those from East Anglia mentioned at the bottom of page 20. Again, in such a short epitome is it not perhaps a pity to have introduced a totally new nomenclature for the glaciations which has not yet been to any extent accepted? The considerable cave excavations of Upper Palæolitbic industries are dismissed in about three sentences, which is scarcely sufficient. The Neolithic Age is allowed three pages. Those who have studied the period will know the subject-matter already, while those who are less instructed will find the discussion far too condensed. But such a work lends itself to criticisms on almost every page, and yet undoubtedly it has a definite value. It covers a far wider range in time than most archæological works dealing with Great Britain, and in spite of criticisms of details, it does give a bird'seye view of what is known of the period under review. The pin-pointing of what is required to be discovered by future investigators is also very useful.

\section{Agricultural and Horticultural Research Station, Long Ashton}

THE annual report of the Agricultural and Horticultural Research Station, Long Ashton, for 1947 has now been published (price 10s.). The problems of the cider industry naturally play a prominent part in the work of the Station, and a list of suitable varieties for planting has been drawn up. Sweet and bitter-sweet sorts are specially advised, since many orchards at present contain too high a proportion of sharp varieties. Studies on the chemical composition of different ciders have been started and already fresh lines for further research work are indicated, which may well lead to results of practical importance. Another group of papers deals with the black currant crop. New varieties are described, and management and manurial treatment discussed. The nitrogen requirement of this crop is particularly high, and composts and stable manure alone have proved inadequate. Both fruit and vegetable crops are included in the investigations on plant nutrition. New methods have been developed for studying molybdenum deficiency in sand culture, while in the soil acidity investigations, some account is given of how the specific effects of aluminium toxicity, manganese toxicity, and calcium deficiency in various crops may be distinguished. As regards plant pests, a fluorine compound, bis-( $\beta$-fluoroethoxymethane), has been found to exert remarkable insecticidal properties, when watered on the soil, on beans and cauliflowers. Although compounds of this type cannot be used in commercial horticulture in view of their extremely poisonous nature, the discovery is of importance, for by it, light may be thrown on the process of trans. location within the plant tissues.

\section{Local Government}

THE problem of the definition of local government areas for one purpose or another is a very complex one. The needs of local administretion have long outgrown the existing framework, and for every aspect of local government the boundaries need to be redrawn. In a paper in the Geographical Journal (111, 4-6) entitled "The Boundaries of Local Government Areas", Mr. E. W. Gilbert discusses some of the problems involved, especially as the geographer sees them, with reference to the "Local Government Boundary Commission Report" for the year 1946. A valuable feature of his paper is the series of twenty maps of England and Wales showing boundaries of areas that have been used or suggested for the different purposes, including gas and coal boards, electricity, railways, hospitals, post office, weather forecasts, and so forth. The divergence of views is obvious from these maps. Provinces or areas, each with a regional consciousness, do occur; there is no question of that; but the difficulty lies in their definitions. Even as regards towns the problem is not easy since town boundaries are arbitrary and do not coincide with the urban areas. Again, it is essential that the confines of an administrative region should embrace an area of which all parts are easily accessible in terms of time and expense. This feature has much to do with the growth of regional consciousness.

\section{"Silva of North America"}

"Srlva of North AMERrCA", the authoritative description of the trees which grow naturally in North America exclusive of Mexico, by Prof. C. S. Sargent, long out of print, has now been reprinted by Peter Smith, 321 Fifth Avenue, New York, 16, in a limited edition, complete with all the illustrations, in fourteen volumes (bound in seven) at 200 dollars net. Permission to reprint these books was granted to Peter Smith by Dr. E. D. Merrill, director of the Arnold Arboretum.

\section{Announcements}

Sir Edward ApPliton, secretary of the Department of Scientific and Industrial Research, has been appointed principal and vice-chancellor of the University of Edinburgh. It has also been announced that Sir Edward has been awarded the Valdemar Poulsen Gold Medal of the Danish Academy of Technical Sciences, "for outstanding contributions to radio technics and partisularly for remarkable achievement in research on the ionosphere". The award was instituted in commemoration of the work of Dr. V. Poulsen, the inventor of the Poulsen arc and a pioneer of radio-telephony, who received the first medal on the occasion of his seventieth birthday on November 23, 1939.

Mr. Roger Dundalfe has been elected chairman of the General Council of the British Standards Institution in succession to the late Sir Clifford Paterson.

THe Council of Scientific and Industrial Research, India, has established an Indian Scientific Liaison Office in London, and Dr. S. Bhagavantam, who was professor of physics in the Andhra University, Waltair (India), has been appointed chief scientific liaison officer. This Office is with the Scientific Liaison Offices of the other Dominions, at Africa House, Kingsway, London, W.C.2.

THE price of Richardson's "Veterinary Protozoology" reviewed in Nature of November 13, p. 756, is given as 10s. net. We are informed by the publishers, Messrs. Oliver and Boyd, Ltd., that the correct price is $18 s$. net. 